\title{
HUBUNGAN SIKAP RELIGIUS DENGAN RASA BERSALAH PADA REMAJA AKHIR YANG BERAGAMA ISLAM
}

\author{
Mochamad Widjanarko \\ Universitas Katholik" Soegijapranata"
}

\begin{abstract}
INTISARI
Tujuan dari penelitian ini adalah untuk mengetahui hubungan sikap raligius dengan rasa bersalah pada remaja akhir yang beragama Islam. Hipotesis yang diajukan aalah ada hubungan positif antara sikap religius dengan rasa bersalah. Semakin tinggi sikap religius yang dimiliki semakin tinggi rasa bersalah pada remaja akhir ter sebut.

Subjek penelitian adalah ramaja yang berusia $17-21$ tahun yang duduk d bangku SMA, beragama Islam dan bertempat tinggal d Kecamatan Banyumanik Semarang berjumlah 100 orang. Analisis statistik yang dipergunakan adalah teknik korelasi Product Moment. Hasil analisis data menunjukkan bahwa ada hubungan positif dan sangat signifikan antara sikap religius a'engan rasa bersalah pada remaja akhir yang beragama islam.
\end{abstract}

Kata kunci : Sikap religius, rasa bersalah, remaja akhir

Mochamaa' Wiajjanarko, lahir of Kudus, 25Januari 1970, a'alahalumnus Fakultas Psikologi Universitas Katolik Soegijapranata, Semarang. Sekarang bekerja pada Lembaga Penelitian dan Pengembangan Masyarakat (Institute of Research and Community Development) Semarang.

\section{PENGANTAR}

T 7 ita sering mendengar orang mengaku 1. beragama tetapi dengan bangga mengatakan bahwa dalam kehidupan sehari-hari ia jdak menjalankan perintah agamanya. Mereka menyangka bahwa tidak menjalankan ibadah kepada Tuhan itu identik dengan kemajuan. Mereka merasa modern dan terpelajar, apabila tidak beribadah. Akan tetapir apabila mereka sampai kepada suatu titik df mana kemampuan untuk menyesuaikan diri dan dalam menghadapi problema besar tidak teratasi, barulah mereka ingat dan ingin berhubungan dengan Tuhan.

Pada waktu-waktu tertentu, saat kita tidak menghendaki, rasa bersalah hadir kembali mengusik ketenangan hati kita. Mesk- 
pun dilupakan, disembunyikan, dan ditutupi, perasaan itu tetap saja hidup dalam hati kita.

Rasa bersalah pada dasarnya adalah emosi manusiawi. Makin berbudaya suatu masyarakat, ma kin besar pula kemungkinan individu tersebut terbebani rasa bersalah. Jika bukan karena adanya rasa bersalah. masyarakat tidak akan ada seperti yang kita kenal sekarang. Masyarakat yang tidak mengenal rasa bersalah akan menjadi masyarakat yang kejam, tidak beraturan. dan tentu saja tidak dapat disebut sebagai masyarakat sesungguhnya (Coleman, 1992: 96).

Zulkifli (1987:102) mengemukakan bahwa rasa bersalah pada individu dipengaruhi oleh faktor-faktor pembawaan, lingkungan, agama, dan usia. Pada individu yang lebih mendalami dan taat akan ajaran agamanya, rasa bersalahnya akan lebih berfungsi. Demikian juga pada individu yang lebih tua usianya, rasa bersalahnya lebih berfungsi bila dibandingkan dengan individu yang berusia lebih muda. Individu yang berada di lingkungan yang memegang teguh normanorma kehidupan rasa bersalahnya akan lebih berfungsi dibandingan dengan individu yang berada di lingkungan yang bersikap acuh tak acuh terhadap norma-norma kehidupan. Faktor pembawaan individu juga ikut mempengaruhi bagaimana rasa bersalah in dividu tersebut. Apabila individu itu cenderung ekstrover, maka rasa bersalahnya kurang berfungsi bila dibandingkan dengan individu yang cenderung introvert.

Rasa bersalah dapat mempengaruhi keseluruhan hidup manusia dan usaha pendukung dalam mengatasi rasa bersalah adalah peranan iman kepada Tuhan, di mana seseorang yang keimanannya telah menguasainya, walau apapun yang terjadi tidak akan mengganggu atau mempengaruhi bahkan keimanan itu akan membawanya kepada ketentraman dan kebahagiaan hati.

Najati (1985: 39-40) mengatakan bahwa manusia itu mempunyai dorongan ber- agama, yaitu dorongan psikis yang mempunyai landasan ilmiah di dalam watak kejadian manusia. Dalam relung jiwanya, manusia merasakan adanya suatu dorongan untuk mencari dan memikirkan Sang Pencipta-Nya dan Pencipta alam semesta.

Sikap religifus adalah keadaan dalam diin seseorang dalam merasakan dan mengakui adanya kekuatan tertinggi yang menaungi kehidupan manusia dengan cara melaksanakan semua perintah Tuhan sesuai dengan kemampuan dan meninggalkan seluruh larangan-Nya, sehingga hal ini akan membawa ketentraman dan ketenangan pada dirinya.

Kesadaran beragama melibatikan seluruh fungsi jiwa raga manusia, yang mencakup aspek-aspek aktif, konatif, kognitif, dan mororik. Fungsi af ektifdan konatifterI hat di dalam pengalaman ketuhanan, rasa keagamaan dan kerinduan kepada Tuhan. Aspek motorik tampak dalam perbuatan dan gerakan tingkah laku keagamaan. Dalam kehidupan sehar-hari, aspek-aspek tersebut sukar dipisah-pisahkan karena merupakan suatu sistem kesadaran beragama yang utuh dalam kepribadian seseorang (Ahyadi, 1991, h.37).

Dalam masa remaja akhir terjadi proses penyempurnaan pertumbuhan fisitk dan perkembangan aspek-aspek psikis yang telah dimulai sejak masa-masa sebelumnya. Arahnya adalah kesempurnaan kematangan. Dijelaskan lebih lanjut oleh Kelly (1955, h.303) bahwa dalam masa remaja, seseorang mempersiapkan diri memasukı masa dewasa Keadaan pribadi, sosial, dan moral remaja akhir berada dalam periode yang kri. tis, dalam penode akhir masa remaja ini individunya diharapkan memiliki kepribadian tersendiri yang akan menjadi pegangan (falsafah hidup) dalam alam kedewasaan.

Berdasarkan tinjauan pustaka serta permasalahan yang dihadapi, maka hipotesis yang diajukan adalah ada hubungan yang 
positif antara sikap religius dengan rasa bersalah pada remaja akhir yang beragama Islam, yaitu semakin tinggi sikap religius yang dimiliki, maka semakin tinggi pula rasa bersalah yang dimilikinya. Sebaliknya semakin rendah sikap religius yang dimiliki, maka semakin rendah pula rasa bersalah pada remaja akhir tersebut.

\section{METODE}

Sampel penelitian adalah remaja akhir yang berusia 17 - 21 tahun yang duduk di bangku SMA, beragama Islam, dan bertempat tinggal d Kecamatan Banyumanik Semarang. Adapun pengambilan sampel menggunakan teknik Fandom Sampling.

Dalam penelitian ini, metode yang dipergunakan adalah metode angket. Angket sikap retigius disusun sebanyak 60 attem yang terdiri dari sujuh aspek, yaitu: differensiasi yang baik, motivasi kehidupan beragama yang baik, pelaksanaan ajaran agama secara konsisten dan produktit, pandangan hidup yang komprehensit, pandangan hidup yang integral, dan semangat pencarian dan pengabdian kepada Tuhan dengan koefisien validitas berkisar antara 0 , 164 sampai dengan 0,662 dan koefisien reliabilitasnya sebesar 0,927. Pada angket rasa bersalah disusun sebanyak 36 aitem yang terdiri dari dua faktor, yaitu rasa bersalah yang timbul dari hubungan prbadi dan rasa bersalah yang berkaitan dengan peran di masyarakat dengan koefisien validitas berkisar antara 0,165 sampai dengan 0,597 dan koefisien reliabilitasnya sebesar 0,874.

Pernyataan dari angket sikap religius terdiri dari pernyataan positif dan pernyataan negatif serta memiliki empat kemungkinan jawaban, yaitu sangat setuju, setuju, tidak setuju, dan sangat:idak setuju, dengan skor bergerak dari 1 sampai 4 untuk negatif dan 4 sampai 1 untuk positif. Pada angke rasa bersalah terdapa: dari pernyataan positif dan pernyataan negatif serta memiliki empat kemungkinan jawaban yang selalu, sering, ka dang-kadang, dan tidak pernah, dengan skor bergerak dari 1 sampai 4 untuk negatif dan 4 sampai 1 untuk positit.

Sesuai dengan hipotesis yang diajukan dan berdasarkan identitas variabel penelitian, jenis data, dan tujuan penelitian, yaitu untuk mengetahui ada tidaknya hubungan antara sikap religius dengan rasa bersalah pada rernaja akhir yang beragama Islam, maka statistik yang digunakan adalah :eknik korelasi Product Moment.

\section{HASIL}

Perhitungan analisis menggunakan ¡eknik korelasi Product Moment, Program SPS (Seri Program Statistik) edisi Sutr।\$no Hadi dan Seno Pamardiyanto versi IBM (1990).

Dari hasil analisis tersebut diperoleh $r_{x y}=$ 0,321 dengan $p<0,0 t$. Dengan demikian dapal dikemukakan bahwa hipotesis penelitian diterma, sehingga ada hubungan yang positif dan sanga: signifikan antara sikap religius antara sikap religius dengan rasa bersalah pada remaja akhir yang beragama islam.

\section{DISKUSI}

Berdasarkan uji hipotesis, diperoleh hasil bahwa hipotesis yang diajukan diterima, yaitu ada hubungan yang positif antara sikap religius dengan rasa bersalah pada remaja akhir yang beragama Islam.

Hasil penelitian ini mendukung asumsiasumsi yang ada. Daradjat(1991, h. 11) mengemukakan unsur terpenting yang membantu pertumbuhan dan perkembangan kejkwaan manusia adalah iman yang direalisasikan dalam bentuk ajaran agama, karena iman itu menjadi pengendali sikap, ucapan, tindakan dan perbuatan. Tanpa kendali tersebut akan mudarkah orang terdorong mela- 
kukan hal-hal yang merugikan dirinya atau orang lain.

Coleman (1992, h. 59) berpendapat bahwa rasa bersalah itu timbul tanpa kita sadari dan bagaimana rasa bersalah itu berpengaruh terhadap kehidupan kita. mempengaruhi keseluruhan hidup kita, dan hal ini yang membuat situasi bertambah buruk. Ketika perasaan bersalah muncul dan tumbuh, sedikit derni sedikit kita makin yakin bahwa hanya kita yang telah gaga I memikul kewajiban umum maupun pribadi. Kita merasa bersalah atas kegagalan kita secara pribadi ataupun orang yang secara pribadi tidak dekat dengan kita.

Dengan intropeksi, dengan melihat baik motif, pengetahuan, dan kesenjangan sewaktu menjalankan perbuatan yang menjadi sumber rasa bersalah, membongkarsebabsebab yang ada di bawah rasa bersalah. iman kepada Tuhan Yang Maha Pengampun, maka orang-Drang yang terhimpit rasa bersalah sedikit demi sedikit dapat membebaskan diri dari perasaan yang menekan hatinya itu. Dengan dibebaskan dari beban batin itu, mereka berubah menjadi manusia yang berwajah cerah dan bergairah untuk menyongsong masa depan mereka (Mangunhardjana, 1991, h. 11-13\}.

\section{KESIMPULAN}

Berdasarkan hasil penelitian yang telah dilakukan dapat disimpulkan bahwa sikap religius yang dimiliki oleh remaja akhir sangat berhubungan dengan rasa bersalah yang timbul. Ketidakmampuan remaja untuk mengatasi sendiri masalahnya menurutcara yang dyakininya, membuat remaja menyadari bahwa penyelesaian masalah tidak selalu sesuai dengan harapan. Rasa bersalah ini timbul tanpa disadari dan bagaimana rasa bersalah itu berpenganh terhadap kehidupan dan mempengaruhi keseluruhan hldupnya, maka remaja akan mudah terdorong untuk melakukan hal-hal yang merugikan dirinya tampa adanya kendali iman yang dimilikinya. Iman menjadi pengendali sikap. ucapan, tindakan dan perbuatan. 7

\section{DAFTAR PUSTAKA}

Ahyadi, A.A. 1991. Psikologi Agana Kepribadian Muslim Indonesia. Bandung: $\mathrm{Pe}$ nerbit Sinar Baru.

Coleman, V. 1992. Psikologi Populer. Rasa Salah, Mengapa ter jadi, bagaimana mengatasinya Jakarta: Penerbit ARCAN.

Daradjat, Z 1991. Islam dan Kesehatan Mental. Jakarta: CV. Haji Masagung.

Kelly, E.L. 1955. Consistency of The Adult Personality American Psychologist.

Mangunhardjana, A.M. 1991. Mengatasi Hambatan-hambatan Kopribadian. Yogyakarta: Penerbit Kanisius.

Najati, U. 1985. Al-Qur'an dan limu Jiwa. Bandung: Pustaka.

Zulkifli, L. 1987. Psikologi Perkembangan. Bandung: Penerit Femaja Karya. 